\title{
Isotope hydrology of dripwaters in a Scottish cave and implications for stalagmite palaeoclimate research
}

\author{
L. Fuller ${ }^{1}$, A. Baker ${ }^{1}$, I. J. Fairchild ${ }^{1}$, C. Spötl ${ }^{2}$, A. Marca-Bell ${ }^{3}$, P. Rowe ${ }^{3}$, and P. F. Dennis ${ }^{3}$ \\ ${ }^{1}$ School of Geography, Earth and Environmental Sciences, University of Birmingham, Birmingham, B15 2TT, UK \\ ${ }^{2}$ Department of Geology and Palaeontology, University of Innsbruck, Innrain 52, Innsbruck, 6020, Austria \\ ${ }^{3}$ School of Environmental Sciences, University of East Anglia, Norwich, NR4 7TJ, UK
}

Received: 6 December 2007 - Published in Hydrol. Earth Syst. Sci. Discuss.: 3 March 2008

Revised: 4 July 2008 - Accepted: 4 July 2008 - Published: 5 August 2008

\begin{abstract}
Dripwater hydrology and hydrogeochemistry is particularly useful in constraining the meaning of speleothem palaeoclimate archives, for example using $\delta^{18} \mathrm{O}$ signatures. Here, we calibrate the relationship between $\delta^{18} \mathrm{O}$ in precipitation, percolation waters and contemporary calcite deposits, at Tartair cave, Sutherland, NW Scotland, an Atlantic site sensitive to regional changes both of temperature and precipitation. Monthly precipitation displayed a $7.1 \%$ orange in $\delta^{18} \mathrm{O}$, a negative linear relationship with rainfall amount, and no correlation with temperature. Autogenically-derived cave percolation waters show little variation in $\delta^{18} \mathrm{O}$ during the same period and their annual weighted mean is the same as that of the local precipitation. This evidence together with hydrological data and electroconductivity values indicates that percolation waters are well mixed and dominated by stored water. Calculated values of $\delta^{18} \mathrm{O}$ of calcite deposited in this cave environment indicate that the cave deposits are forming close to isotopic equilibrium and kinetic effects are negligible. Comparison of a high-resolution $\delta^{18} \mathrm{O}$ stalagmite record with the instrumental record of climate indicates that isotopically heavy values are reflective of relatively cold, dry conditions (and vice-versa for warm, wet condition) and hence that stalagmite oxygen isotopes provide an appropriate means of investigating the palaeoclimate in this location.
\end{abstract}

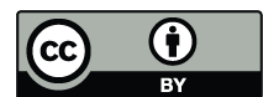

Correspondence to: I. J. Fairchild (i.j.fairchild@bham.ac.uk)

\section{Introduction}

The hydrological behaviour of small water volumes becomes particularly important when they feed, and hence control, the composition of growing calcareous deposits (speleothems) in karstic cavities. Speleothems are recognised as important continental archives of palaeoenvironmental information: they can be accurately dated using U-series techniques and their subterranean location means that they can accumulate undisturbed for thousands of years. Their ${ }^{18} \mathrm{O} /{ }^{16} \mathrm{O}$ ratios can be used to reconstruct climate, although the rationale used can sometimes be complex and in need of further testing (McDermott, 2004; Fairchild et al., 2006a). Major longterm shifts in $\delta^{18} \mathrm{O}$ can sometimes be shown to be directly controlled by changing climate systems, independent of details of the cave environment (e.g. Wang et al., 2001). However, where the changes in $\delta^{18} \mathrm{O}$ are more subtle (e.g. in nonmonsoonal areas in the Holocene), an understanding of how these surface climate signals are transmitted from meteoric precipitation to a speleothem via the soil and groundwater system is essential in order for this isotopic information to be utilized (Fairchild et al, 2006a; Mickler et al., 2006). There are two major forcing factors which can change the ${ }^{18} \mathrm{O} /{ }^{16} \mathrm{O}$ ratio of calcite deposits: a change in the isotopic composition of the precipitation feeding the speleothem, or a change in cave temperature. The oxygen isotopic composition of precipitation $\left(\delta^{18} \mathrm{O}_{\mathrm{ppt}}\right)$ in different regions can be controlled by the extent of temperature-related Rayleigh fractionation in the atmosphere, or may inversely correlate with the amount of rainfall, or show more complex effects, including controls by moisture source (Rozanski et al., 1993; Hoffman et al., 1998; Mook, 2000). The western seaboard of Europe displays complex controls such that changes in $\delta^{18} \mathrm{O}$ over time cannot be predicted from first principles because the relationship between isotopic composition, synoptic weather

Published by Copernicus Publications on behalf of the European Geosciences Union. 


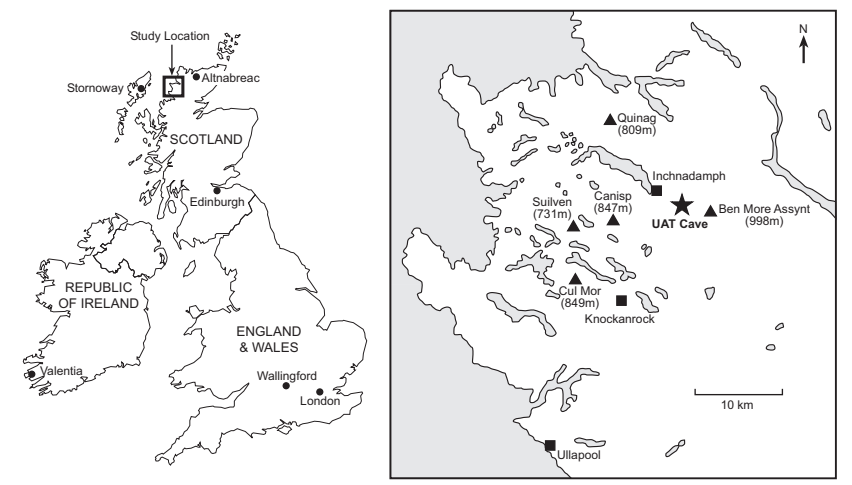

Fig. 1. (a) Location of Assynt study area and other significant geographic and monitoring locations within the British Isles. (b) The Assynt area of NW Scotland and the location of the Tartair (UAT) cave system.

processes, and climatic modes have been incompletely explored. For example, in the UK there is normally a relationship between seasonality of temperature and summer and winter $\delta^{18} \mathrm{O}$ signatures (Darling and Talbot, 2003), but such a correlation does not imply a simple causality (Treble et al., 2005a). The second control on calcite ${ }^{18} \mathrm{O} /{ }^{16} \mathrm{O}$ ratio is cave temperature which, away from the entrance, is very close to the mean annual air temperature (MAT) outside the cave (Wigley and Brown, 1976). An increase in cave temperature will lead to calcite becoming isotopically lighter.

Speleothem ${ }^{18} \mathrm{O} /{ }^{16} \mathrm{O}$ is also susceptible to local forcing factors. Processes such as transpiration from vegetation above the cave (Williams and Fowler, 2002) and vegetation change over time (Baldini et al., 2005), evaporation of soil waters (Bar-Matthews et al., 1996; Denniston et al., 1999), and mixing within the karstic aquifer (Williams and Fowler, 2002; Yonge et al., 1985) have all been shown to play a role in changing the isotopic composition between rainfall and the emerging cave drip waters. The influence of the karst system upon drip hydrology in turn affects the majority of geochemical signals preserved in the subsequently deposited stalagmite calcite, the route taken by the percolating water being of primary importance. Physical characteristics of cave percolation waters are diverse (e.g. Gunn, 1981; Mangin, 1975; Atkinson, 1977) and can be classified for example in terms of mean and variance of discharge (Friederich and Smart, 1982). Conceptually this can be related to varying inputs from conduit, fracture and matrix porosity in a tripleporosity aquifer (Tooth and Fairchild, 2003; Fairchild et al., 2006b). Nevertheless, the biphase (air-water) nature of the feeding system, pressure variations, and geometrical complexities result in significant non-linear behaviours of dripwaters (Destombes et al., 1997; Genty and Deflandre, 1998; Baker and Brunsdon, 2003), including inter-annual variability (Baldini et al., 2006). The hydrology of stalagmite feeding percolation waters must be monitored in order to under-

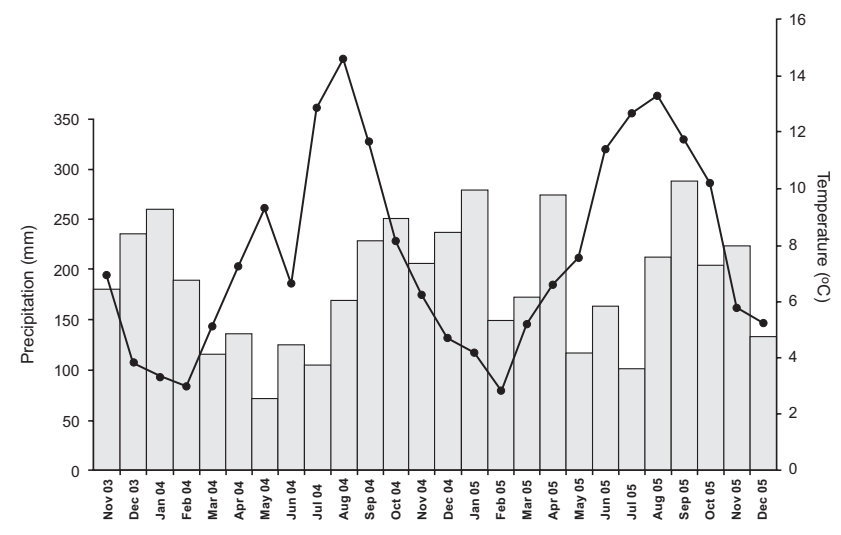

Fig. 2. Chart summarising calculations of monthly precipitation (bars) and monthly mean temperature (solid black line) for Knockanrock from Stornoway data as described in text.

stand the nature of the percolation water and its evolutionary pathway (reservoirs, residence times, response to periods of heavy rainfall such as flow switching, or drought), as well as identifying any offset in composition from that of atmospheric precipitation.

Few studies have monitored cave systems in sufficient detail to understand and correctly interpret the controlling influences, although it has been found that in mid-latitudes cave drip waters generally reflect the mean annual isotopic composition of the precipitation in the local area (Caballero et al., 1996; Williams and Fowler, 2002; Yonge et al., 1985). Where drip discharge varies little and seepage flow can be inferred, no seasonal variation in $\delta^{18} \mathrm{O}$ is found, whereas when a component of fracture-fed flow is present, such variations should be present (e.g. Fairchild et al., 2006a, b) and indeed have been identified in both dripwaters (e.g. van Beynen and Febbroriello, 2006) and speleothems (Treble et al., 2005b).

In the study presented in this paper, we have gone beyond previous work by comparing the isotopic composition of drips in the modern cave with a high-resolution $\delta^{18} \mathrm{O}$ record from an annually-laminated speleothem fed by one of the studied drips which allowed comparison with the instrumental climate record and hence permitted a more thorough test of the suitability of stalagmites from this site for palaeoclimate determination.

\section{Study site}

The study cave is in the Assynt area, located on the North Atlantic seaboard of NW Scotland (Fig. 1). Based on 1971-2000 averages, the regional climate is oceanic with $>1900 \mathrm{~mm}$ rainfall, 250-270 rain days per year, 4-6 snow days, and an average of $77 \%$ cloud cover annually (Proctor et al., 2000). Mean annual air temperature is $7.1^{\circ} \mathrm{C}$ (Fig. 2). The Assynt area shows a relationship between precipitation and the winter North Atlantic Oscillation Index (NAO), and 
temperature and ocean circulation via the North Atlantic drift (Colman, 1997; Hurrell, 1995). The NAO is a large-scale fluctuation in atmospheric pressure between the subtropical high pressure system located near the Azores in the Atlantic Ocean and the sub-polar low pressure system near Iceland and is quantified in the NAO Index, which is the pressure difference between the two. NW Scotland displays higher mean annual precipitation occurring during years with a more positive winter NAO index associated with a stronger westerly circulation and higher frontal rainfall (Proctor et al., 2000, 2002). Hurrell (1995) found a high $r$ value of 0.75 for the correlation between winter (December to March) NAO index and winter precipitation at Stornoway. We have found that there is also a significant correlation $(r=0.56)$ between annual water index and annual NAO index. Annual stalagmite growth bands from the study site have been used to reconstruct past rainfall patterns (Proctor et al., 2000, 2002), northern hemisphere temperature (Smith et al., 2006) and snow cover (Baker et al., 2002).

The studied cave chamber is within the Cnoc nan Uamh (Gaelic for Cave Knoll) cave system (National Grid Reference NC276206, Lawson, 1988), situated $3 \mathrm{~km}$ east of Inchnadamph and $220 \mathrm{~m}$ above OD (Fig. 1). The entrance is through a stream passage close to a waterfall which inspired the name Uamh an Tartair (Roaring Cave) and we use Tartair as the generic site name. Tartair is developed in Cambro-Ordovician dolomite, dipping at shallow angles, and containing a thin igneous sill; bedrock is overlain by peat. It is situated within the Traligill Basin, a peat dominated catchment (near-basal radiocarbon peat age above the cave of $2130 \pm 180$ cal y BP) (Charman et al., 2001). Cnoc nan Uamh is small, shallow and complex cave system with three known entrances (Lawson, 1988). Water to this cave is supplied both autogenically (from seepage water derived directly from the peat covered surface) and allogenically (by an active underground stream which runs through the cave system). The Grotto is a well-decorated chamber $\sim 40 \mathrm{~m}$ from the main cave entrance, and $\sim 10 \mathrm{~m}$ below the surface; it contains a high density of drip sites with a high soda straw density. In the Grotto area various inlets supplied by autogenic percolation water were selected for monitoring; all of these are actively depositing soda straw stalactites and underlying stalagmite deposits. Previous unpublished monitoring by one of us (AB) in the 1990s found the mean annual temperature and relative humidity to be $7.1^{\circ} \mathrm{C}$ and $>98 \%$ respectively. In the current period of monitoring, the temperature range determined from Tinytag monitors left in the Grotto was 4.8 to $9.5^{\circ} \mathrm{C}$, with a mean of $7.2^{\circ} \mathrm{C}$.

\section{Materials and methods}

Monthly bulk precipitation samples for isotopic analysis were collected from Inchnadamph ( $3 \mathrm{~km}$ from the cave), using a plastic rain gauge, $0.5 \mathrm{~m}$ above ground level; paraffin oil was added to prevent evaporation. Each sample was taken on the last day of the month from November 2003-November 2005, but there were two missing months in the second year of sampling.

Cave drip water samples were collected from thirteen, hydrologically diverse drip sites over two hydrological years, at a resolution of two to three months. Drip waters were collected in high density polypropylene (HDPE) bottles over a period of 24-28 h; after collection they were sealed and refrigerated until analysis. Ancillary information collected includes the drip interval (time between drips) and electroconductivity (EC), the latter using a WTW Multi 340i instrument, automatically correcting data to $25^{\circ} \mathrm{C}( \pm 0.5 \%)$. Ionic analyses (Fuller, 2007) confirm that EC is a good proxy for the total ion content derived from carbonate dissolution, i.e. dissolved calcium, magnesium and bicarbonate concentrations.

Oxygen and hydrogen isotope measurements of waters were carried out at the University of East Anglia using $\mathrm{CO}_{2}$-equilibration for $\delta^{18} \mathrm{O}$ (precision $0.06 \%$ ) and by reduction using glassy carbon chips in continuous flow for $\delta \mathrm{D}$ measurements (procedure modified from Begley and Scrimgeour (1997). Each groundwater sample was replicated and an internal laboratory reference water was measured after every third sample. External precision was $2 \%$.

The isotopic ratio of the contemporary calcite was measured at the University of Innsbruck, Austria. Calcite was sampled at high resolution from two Tartair stalagmites SU96-7 and SU03-2 (whose drip waters have also been collected), using a micromill system, using continuous trenches, with a resolution of $0.1 \mathrm{~mm}$ in the growth direction. The drilled stalagmite powders were then analyzed for $\delta^{18} \mathrm{O}$ using a continuous-flow isotope-ratio mass spectrometer; for analytical details see Spötl and Vennemann (2003).

Isotope values are reported in delta units, which are permil deviation of the isotopic ratio from a standard:

$\delta($ in $)=\left(\left(R_{\text {sample }}-R_{\text {standard }}\right) / R_{\text {standard }}\right) \cdot 1000$

where $R$ is the ratio of heavy to light isotope. The standard for reporting water isotopes is Vienna standard mean ocean water (V-SMOW) and for oxygen is calcite is Vienna Pee Dee Belemnite (V-PDB).

Precipitation and temperature data for Stornoway (see Fig. 1 for location) from AD 1873 to 2006 were obtained from the UK meteorological office. This was correlated with existing precipitation and temperature data (AD 1963-1996) for Knockanrock (National Grid Reference NC187088, Fig. 1), $80 \mathrm{~km}$ SE of Stornaway and $12 \mathrm{~km} \mathrm{SW}$ of the Tartair site at a similar altitude and aspect. A positive linear relationship was found between Stornoway and Knockanrock for both temperature $(r=0.99)$ and precipitation $(r=0.84)$, both significant at the $99.9 \%$ confidence interval (Proctor et al., 2000). This relationship was then used to calculate Knockanrock precipitation and temperature from July 1874 to the present (November 2003 to December 2005 
Table 1. Summary data (per mil versus V-SMOW) of $\delta^{18} \mathrm{O}$ and $\delta^{2} \mathrm{H}$ (values in parentheses) in monthly precipitation at Inchnadamph.

\begin{tabular}{lrr}
\hline & $\begin{array}{r}\text { Year 1 } \\
\text { (December 2003 } \\
\text {-November 2004) }\end{array}$ & $\begin{array}{r}\text { Year 2 } \\
\text { (December 2004 } \\
\text {-November 2005) }\end{array}$ \\
\hline Mean & $-6.6(-49.9)$ & $-6.6(-51.5)$ \\
Minimum & $-10.7(-74.3)$ & $-8.6(-68.8)$ \\
Maximum & $-3.6(-26.5)$ & $-5.0(-37.1)$ \\
Range & $7.1(47.7)$ & $3.7(31.7)$ \\
Summer Mean (AMJJAS) & $-5.7(-43.8)$ & $-6.4(-52.0)$ \\
Winter Mean (ONDJF) & $-7.5(-56.0)$ & $-7.0(-52.0)$ \\
Weighted Mean & $-7.1(-53.3)$ & (data incomplete) \\
Number of Data Points & 12 & 10 \\
\hline
\end{tabular}

shown in Fig. 2). The soil moisture budget was calculated from these data using the equation of Thornthwaite (1948). Temperature in the Tartair Grotto was logged from November 2003 to November 2005 using Tinytag Plus temperature loggers (sensor accuracy of $0.2^{\circ} \mathrm{C}$ ) programmed to record temperature at $15 \mathrm{~min}$ intervals.

\section{Results}

\subsection{Isotopic composition of precipitation}

The mean annual $\delta^{18} \mathrm{O}$ of the local precipitation $\left(\delta^{18} \mathrm{O}_{\mathrm{ppt}}\right)$ over the 2-y collection period is given in Table 1 . For each year the mean $\delta^{18} \mathrm{O}_{\mathrm{ppt}}$ is $-6.6 \%$, although there is more variation during the first year $(7.1 \%$ ) than the second $(3.7 \%$ o). The data shows some evidence of seasonality; during the first year this is highlighted by the difference between the summer $(-5.7 \%$ ) and winter $(-7.5 \%)$ mean values. The annual amount-weighted $\delta^{18} \mathrm{O}$ value for Inchnadamph precipitation is $-7.1 \%$ o. This is $1.7 \%$ o heavier than the amount weighted value of $\delta^{18} \mathrm{O}_{\mathrm{ppt}}$ calculated for the nearest Global Network of Isotopes in Precipitation (GNIP) site at Altnabreac, Caithness (Fig. 1), which existed for a 13 month period from 1980 to 1981 (Kay et al., 1984).

A strong linear relationship exists between $\delta^{18} \mathrm{O}$ and $\delta^{2} \mathrm{H}$ in Inchnadamph monthly precipitation $(r=0.98)$, demonstrated by the linear regression shown in Fig. 3, which represents the local meteoric water line (LMWL). The Global Meteoric Water Line (GMWL) is also shown in Fig. 3. The Inchnadamph LMWL slope (7.05) is similar to other UK sites, for example $7.02 \pm 0.10$ for Wallingford (GNIP, 2002) and $6.32 \pm 0.79$ for Altnabreac (GNIP, 2002).

\subsection{Percolation water hydrology and ion content}

The drip water inlets monitored within the Grotto area of Cnoc nan Uamh cave system are hydrologically diverse with a large range in mean discharges by a factor of nearly 1000

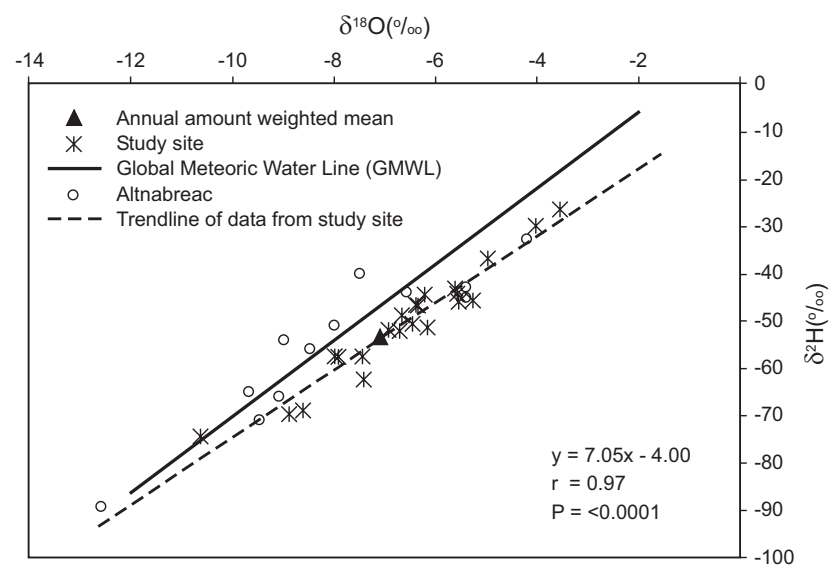

Fig. 3. Relationship between $\delta^{18} \mathrm{O}$ and $\delta^{2} \mathrm{H}$ in monthly precipitation samples collected at the study site (stars). Data for Altnabreac (open circles) and the Global Meteoric Water Line (black line) are also shown for reference. The black triangle shows the annual amount weighted value for the first monitoring year (2003-2004).

(Table 2). The coefficient of variation $\left(C V_{Q}\right)$, the quotient of the standard deviation and the mean discharge expressed as a percentage, provides a suitable dimensionless assessment of discharge variability (Friederich and Smart, 1982), whereas the maximum discharge $\left(Q_{\max }\right)$ reflects the transmission capacity. In the classification updated by Baker et al. (1997), the Tartair drips are all in low $Q_{\max }$ categories, being either seepage flow where $C V_{Q}$ is $<50 \%$, otherwise seasonal drips, the latter being indicative of a more seasonal or "flashy" response to surface events such as high rainfall and a tendency to stop flowing during dry periods (Baker et al., 1997), during which the limestone unsaturated zone is decoupled from rainfall input, and inlets are fed from storage (Smart and Friederich, 1987; Williams and Fowler, 2002). It is notable that the dripsite corresponding to our studied stalagmite, SU96-7, has a combination of a very slow drip rate and the lowest $C V_{Q}$ value of $6 \%$ (Table 2) indicative of a large storage component which feeds the drip throughout periods of drier weather. Maximum discharges measured significantly underestimate the true figures since the cave was not accessible during heavy rainfall events and peak snowmelt. However only a minor component of stalagmite growth would occur during the wet events that have not been directly observed, and so the isotopic data of the water should be more representative from this perspective.

The long inferred mean storage time raises the question of the extent to which a climate signal will be smoothed or lagged in a speleothem deposit. Proctor et al. (2000) examined the phenomenon of autocorrelation of lamina thicknesses from stalagmite SU96-7 and, together with more recent unpublished modelling, it is clear that there is a decadal smoothing process. However, this may well relate mainly to soil processes (e.g. slow recovery from cracking in peat) 
Table 2. Summary statistics for the Grotto drip site discharge data (assuming a drip volume of $0.17 \mathrm{~cm}^{3}$, as in the study of Baker et al., 1997). A coefficient of variation of $<50 \%$ defines seepage flow, whereas $>50 \%$ is referred to as a seasonal drip (Baker et al., 1997). Summary statistics are based upon all discharge data collected including previous unpublished data of A. Baker (1997-2000). Note drip site S15 was monitored by A. Baker but was discontinued during this study. Conductivity data is only from the current study.

\begin{tabular}{|c|c|c|c|c|c|c|c|}
\hline $\begin{array}{l}\text { Drip } \\
\text { Site }\end{array}$ & $\begin{array}{l}\text { Mean } \\
\text { (stdeviation) } \\
\text { Discharge } \\
(\mu 1 / s)\end{array}$ & $\begin{array}{l}\text { Coefficient of } \\
\text { Variation } \\
\left(C V_{Q}\right)\end{array}$ & $\begin{array}{l}\text { Minimum } \\
\text { Discharge } \\
(\mu 1 / s)\end{array}$ & $\begin{array}{l}\text { Maximum } \\
\text { Discharge } \\
(\mu 1 / \mathrm{s})\end{array}$ & $\begin{array}{l}\text { Number of } \\
\text { Observations }\end{array}$ & $\begin{array}{l}\text { Mean (standard deviation) } \\
\text { of electroconductivity } \\
\mu \mathrm{S} / \mathrm{cm}\end{array}$ & $\begin{array}{l}\text { Number of } \\
\text { Observations }\end{array}$ \\
\hline $\mathrm{S} 1$ & $36.9(23.6)$ & 64 & 1.6 & 90.9 & 11 & $502(24)$ & 9 \\
\hline $\mathrm{S} 2$ & $0.9(0.8)$ & 93 & 0.2 & 3.2 & 17 & $477(14)$ & 6 \\
\hline S3 & $0.4(0.1)$ & 34 & 0.1 & 0.6 & 17 & $456(7)$ & 9 \\
\hline $\mathrm{S} 4$ & $0.046(0.1)$ & 144 & 0 & 0.2 & 9 & & \\
\hline S5 & $0.7(0.2)$ & 29 & 0.4 & 1.1 & 15 & $463(4)$ & 7 \\
\hline S6 & $0.1(0.1)$ & 45 & 0.1 & 0.3 & 16 & $450(13)$ & 6 \\
\hline S7 & $0.4(0.1)$ & 14 & 0.3 & 0.6 & 18 & 454(9) & 8 \\
\hline S8 & $0.1(0.1)$ & 51 & 0 & 0.2 & 11 & $434(29)$ & 3 \\
\hline S12 & $16.4(17.5)$ & 107 & 0.5 & 56.0 & 22 & $483(26)$ & 9 \\
\hline S13 & $3.7(6.5)$ & 175 & 0.1 & 20.0 & 20 & $430(25)$ & 8 \\
\hline S15 & $5.0(5.3)$ & 106 & 0.1 & 12.5 & 14 & & \\
\hline SU96-7 & $0.051(0.0)$ & 6 & 0.05 & 0.06 & 8 & $469(25)$ & 3 \\
\hline SU031 & $0.3(0.1)$ & 23 & 0.2 & 0.4 & 10 & $537(29)$ & 9 \\
\hline SU03-2 & $0.5(0.3)$ & 56 & 0.1 & 0.8 & 10 & $547(28)$ & 7 \\
\hline
\end{tabular}

rather than aquifer mixing. Mean residence of the dominant stored component is hence likely to be in the range 1 to $10 \mathrm{y}$, but tracer testing would be needed to provide more information. At other (deeper) cave sites, much longer and variable storage times might be reflected by storage compartments, but there is little observational evidence bearing on this question. In the future, comparison of different stalagmite records (with annual chronology) from sites with different percolation characteristics could throw light on this question. The electroconductivity data display a limited range of mean values (Table 2), consistent with the observed supersaturation of all the drips. There is no universal relationship between hydrology and ion content, although most seasonal drip sites display greater electroconductivity variation. Most sites also display a negative relationship of electroconductivity and discharge, consistent with some dilution by a quickflow component. The slow driprate of site 96-7 made it difficult to collect sufficient sample for EC measurement, but three observations lay well within the range of other samples. In summary, the low variability of electroconductivity values points to the dominance of storage flow and the greater variation in discharge is therefore likely to reflect mainly piston flow accelerating the discharge of stored water, together with a small quickflow component.

A time-series plot of all the cave drip site $\delta^{18} \mathrm{O}$ throughout the surveillance period is given in Fig. 4c. A number of points are worth noting. Firstly the $\delta^{18} \mathrm{O}$ of the cave drip sites, with a few exceptions, appear to vary synchronously through time. Monitoring visits with the least drip water $\delta^{18} \mathrm{O}$ variation occur at the end of the driest period (July 2004): this could be indicative of overwhelming reliance on stored water by all cave drip water sites at this time. The range of $\delta^{18} \mathrm{O}$ values displayed by the drip waters is significantly attenuated when compared to those of the local precipitation and show little (much reduced) seasonality (Fig. 4d). This suggests that cave drip waters are well mixed and that the bulk of the water is stored in the overlying karst for periods in excess of $1 \mathrm{y}$.

\subsection{Oxygen isotope composition of cave percolation waters}

The lightest $\delta^{18} \mathrm{O}$ value recorded for drip water is $-7.66 \%$ and the heaviest is $-5.99 \%$ (Table 3 ), and the range of values recorded is quite muted, from $0.36 \%$ at $\mathrm{S} 2$ to $1.19 \%$ at S5. There does not appear to be any overall difference between drip sites classified as "seepage flow" and those termed "seasonal". The total range of all drip sites is $1.67 \%$ over the two year monitoring period. The mean of the $\delta^{18} \mathrm{O}$ of drip sites during the first monitoring year (2003-2004) is -7.18\%o, identical within error with the mean of $-7.09 \%$ during the whole monitoring episode. Several points should be borne in mind when making comparison between precipitation and percolation water composition. Firstly, the sampling visits were not monthly in resolution. Secondly the cave drip water samples analyzed are grab samples of water at the time of the field visit and not monthly bulk samples. Thirdly the field visits are biased to spring/summer times when access to the cave system is less likely to be prevented by adverse weather 
Table 3. Summary statistics for the $\delta^{18} \mathrm{O}$ of Cnoc nan Uamh cave drip sites and pool waters through the monitoring period (December 2003-November 2005).

\begin{tabular}{lcccccc}
\hline Drip Site & Mean & StDev & Min & Max & Range & $\begin{array}{c}\text { Number } \\
\text { of Obser- } \\
\text { vations }\end{array}$ \\
\hline S1 & -6.90 & 0.38 & -7.17 & -5.99 & 1.18 & 9 \\
S2 & -7.27 & 0.12 & -7.41 & -7.05 & 0.36 & 6 \\
S3 & -7.18 & 0.15 & -7.38 & -6.90 & 0.48 & 9 \\
S4 & -6.89 & 0.38 & -7.34 & -6.25 & 1.09 & 7 \\
S5 & -6.92 & 0.40 & -7.23 & -6.04 & 1.19 & 8 \\
S6 & -7.22 & 0.15 & -7.41 & -6.92 & 0.49 & 9 \\
S7 & -7.21 & 0.22 & -7.47 & -6.75 & 0.72 & 9 \\
S8 & -7.13 & 0.18 & -7.34 & -6.79 & 0.54 & 9 \\
S12 & -6.97 & 0.27 & -7.22 & -6.45 & 0.77 & 9 \\
S13 & -7.00 & 0.27 & -7.22 & -6.45 & 0.77 & 8 \\
SU96-7 & -7.07 & 0.36 & -7.63 & -6.47 & 1.17 & 8 \\
SU031 & -7.07 & 0.27 & -7.46 & -6.63 & 0.83 & 9 \\
SU03-2 & -7.30 & 0.20 & -7.66 & -7.11 & 0.56 & 7 \\
Cave Pool & -7.15 & 0.29 & -7.39 & -6.54 & 0.85 & 7 \\
\hline
\end{tabular}

conditions. The inaccessibility of the cave during high rainfall events further biases the $\delta^{18} \mathrm{O}$ data of the cave drip sites. Nevertheless, it is remarkable that the mean percolation values are the same as the annual mean amount-weighted value of precipitation (Table 1).

\section{Discussion}

\subsection{Relationship with climate}

In this section, we examine whether the composition of atmospheric precipitation has a relationship to climate and whether such a relationship is likely to be stationary. There is no correlation between the monthly $\delta^{18} \mathrm{O}_{\mathrm{ppt}}$ values during the two year sampling period and either the local temperature or the North Atlantic Oscillation (NAO) index. However, the $\delta^{18} \mathrm{O}_{\mathrm{ppt}}$ shows a negative linear correlation with local precipitation amount, with an $r$-value of -0.42 which is statistically significant at the 0.01 level. Isotopically less negative values occur during the summer months when monthly precipitation totals are lower (Fig. 2) and vice versa. This manifestation of the "amount effect" probably relates to the behaviour of synoptic weather systems, but has not been investigated further.

In contrast to this record, there is a positive $(r=0.47)$ and statistically significant correlation between the monthly temperature and $\delta^{18} \mathrm{O}_{\mathrm{ppt}}$ for Valentia, Ireland (1960-2000), a site similar to Assynt in terms of latitude and proximity to the North Atlantic. This suggests that a longer monitoring period is required to reveal a temperature influence on isotopic composition. One way we can examine the adequacy of the monitoring length in Assynt is to perform a mov- ing correlation on a longer data series and assess whether the $r$-value observed between variables during any 24 month window differs significantly to that overall. For this we used the continuous 20-y data set for GNIP site Wallingford (Fig. 1), southern England (Fig. 5), since there are gaps in the Valentia record. The $r$-values for the long-term (20-y) relationship between $\delta^{18} \mathrm{O}_{\mathrm{ppt}}$ and temperature $(r=0.54)$ and precipitation $(r=-0.45)$ are represented by the thick horizontal lines and data for the period 2004-2005 are close to these means. However, Fig. 5 highlights that for any shorter period at a given monitoring site the shorter term (ca. 1224 months) mean can vary significantly. For example, in period 1 (ca. 1987-1989) in Fig. 5, if a monitoring study had been performed the relationship between $\delta^{18} \mathrm{O}_{\mathrm{ppt}}$ and climate (monthly PPT amount and $T$ ) would be very different to both the long-term 20-y relationship and that which would be established during another shorter time-slice e.g. period 2 (1994-1997). In period 1 there is a positive relationship with precipitation amount and a weaker positive correlation with temperature, whereas in period 2 , there is a stronger negative correlation to precipitation amount and a stronger positive relationship with temperature. In summary, the nonstationary relationships of $\delta^{18} \mathrm{O}$ with climate parameters in the UK context implies that empirical correlations must be used and modern speleothems can be used for this purpose.

\subsection{Contemporary calcite}

In this section, we explore whether the modern precipitates in the cave have an equilibrium composition as predicted from cave temperature and isotopic composition of the dripwaters. From the range of measured air temperatures within the Grotto (Table 4) and the range of $\delta^{18} \mathrm{O}$ measured from drip sites SU96-7 and SU03-2 (Table 3), a predicted range of $\delta^{18} \mathrm{O}$ for calcite $\left(\delta^{18} \mathrm{O}_{c}\right)$ deposited under these conditions can be calculated (Table 5). These values are compared to actual values of $\delta^{18} \mathrm{O}_{c}$ of the top $1 \mathrm{~mm}$ of two Cnoc nan Uamh stalagmites. Stalagmite SU96-7 (Proctor et al., 2000) was actively growing in 1996 when collected. Stalagmite SU032 from the same cave system was actively growing when collected in 2003. The top $1 \mathrm{~mm}$ from SU96-7 represents calcite deposited between AD 1960 and 1996, a period of $36 \pm 1$ y (Proctor et al., 2000). A lamina count on the top of stalagmite SU03-2 (unpublished data) confirms that this sample was deposited more recently and in a much shorter time period of approximately 9-10 y (between $\sim$ AD 1995 and 2003) The predicted $\delta^{18} \mathrm{O}_{c}$ calculated using mean annual air temperature and the mean annual $\delta^{18} \mathrm{O}$ of the drip waters is $-5.6 \%$ (Table 5). This compares with the measured $\delta^{18} \mathrm{O}_{c}$ of $-5.1 \%$ and $-5.3 \%$ o for stalagmites SU96-7 and SU032 , respectively (Table 6). The calcite values are closer to the $\delta^{18} \mathrm{O}$ of calcite predicted using cave minimum temperature $\left(4.8^{\circ} \mathrm{C}\right)$. This may suggest that a significant proportion of the deposited calcite occurs during colder winter months. This would be logical since cave air $\mathrm{CO}_{2}$ concentration is 

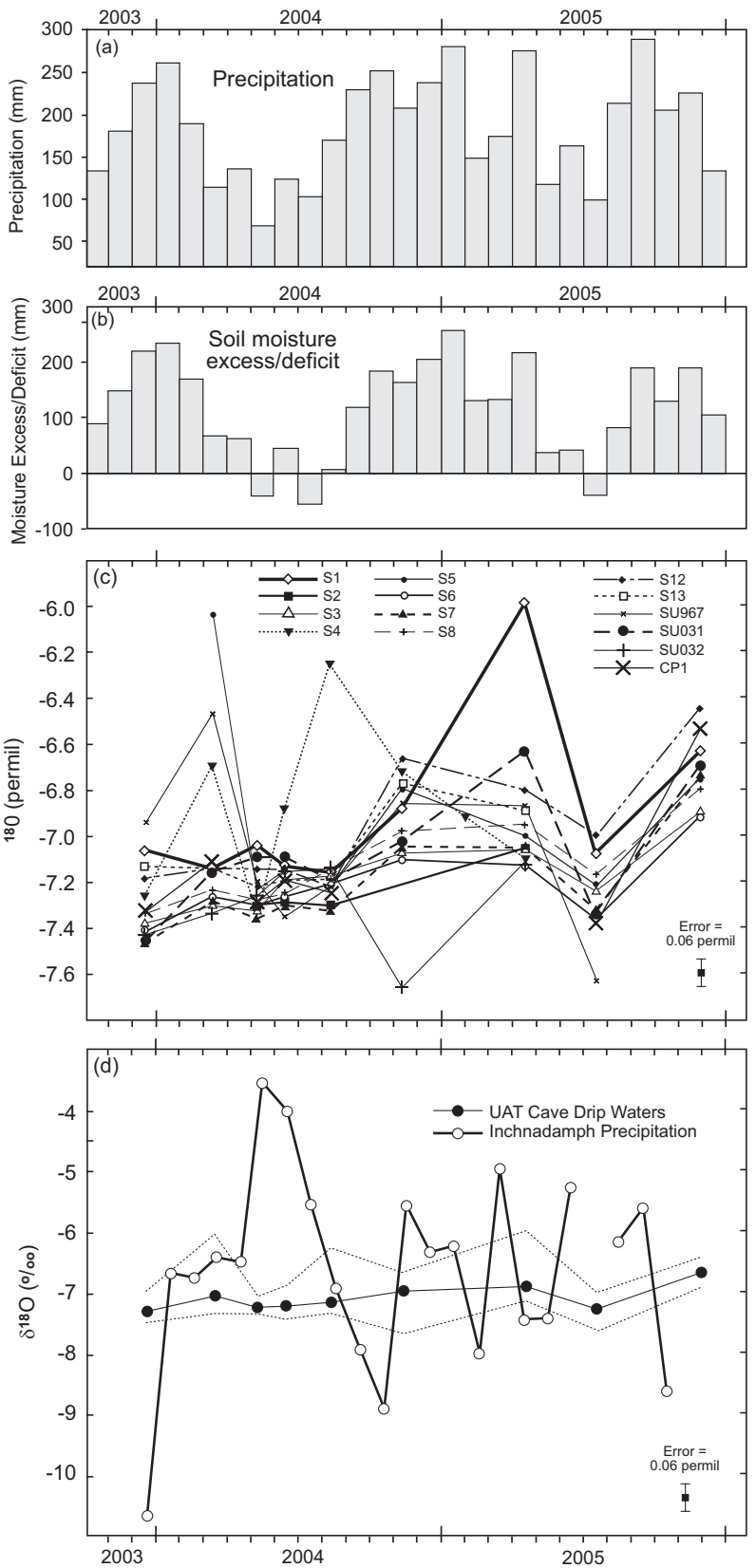

Fig. 4. Hydrology conditions and dripwater $\delta^{18} \mathrm{O}$ values during the monitoring period. (a) and (b) respectively monthly precipitation and soil moisture budget calculated using Thornthwaite equation (1948), (c)) $\delta^{18} \mathrm{O}$ of individual drip water sites, (d) mean dripwater values (plus range indicated by dashed lines) in comparison with bulk monthly precipitation values.

lower during winter time leading to higher supersaturations for calcite (Fuller, 2007). Elsewhere, small (less than 1\%o), but systematic offsets to higher $\delta^{18} \mathrm{O}_{c}$ values have been interpreted as non-equilibrium deposition (McDermott et al., 2005), and larger kinetic effects were found in a Caribbean cave by Mickler et al. (2006). Alternatively, if the experi-

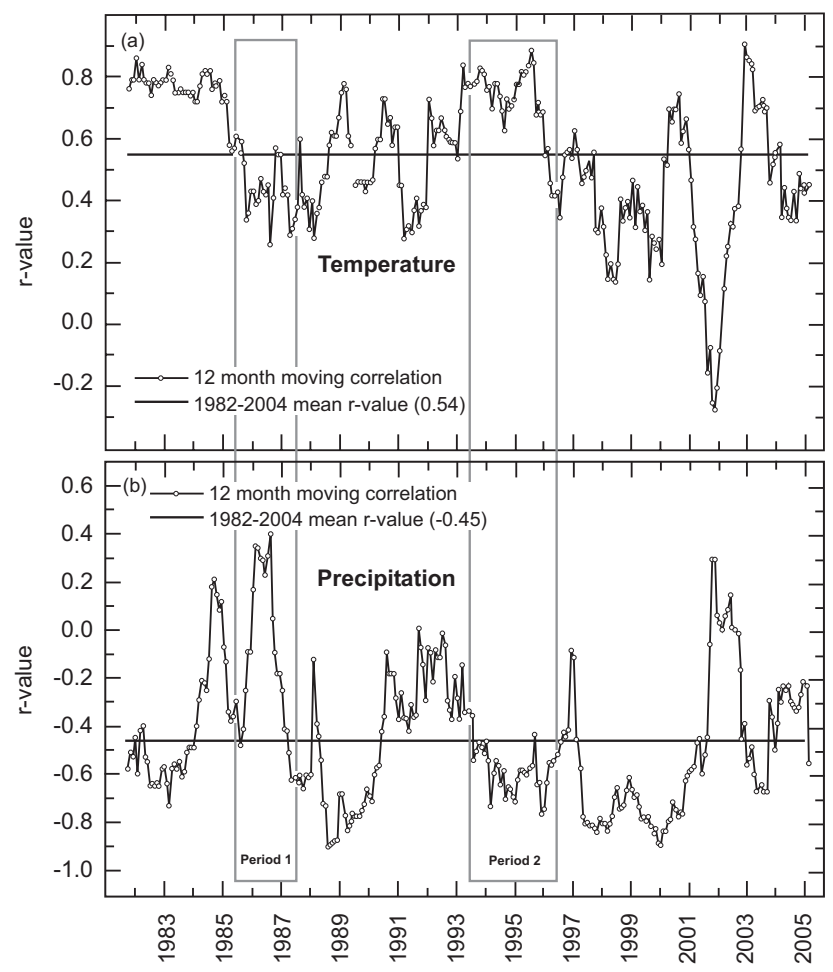

Fig. 5. Moving correlation through the continuous 20-y. (AD 19822004) IAEA-GNIP Wallingford (southern England) data (a) shows 12-month moving correlation between $\delta^{18} \mathrm{O}_{\mathrm{ppt}}$ and temperature (b) shows 12-month moving correlation between $\delta^{18} \mathrm{O}_{\mathrm{ppt}}$ and monthly precipitation totals. The oxygen isotope data at Wallingford were discussed in Darling and Talbot (2003).

Table 4. Summary 12-month temperature logging data (20042005) in degrees $C$.

\begin{tabular}{lcccc}
\hline Monitoring Location & Mean & Min & Max & Range \\
\hline Grotto & 7.2 & 4.8 & 9.5 & 4.7 \\
Exterior & 7.2 & -1.7 & 20.7 & 22.3 \\
\hline
\end{tabular}

mental data of Friedman and O'Neil (1977) are used for calibration, a predicted mean calcite value of $-5.0 \%$ is found suggesting equilibrium deposition. However in any case, the cold cave temperatures (minimizing evaporation), the steady non-flashy nature of the cave drip waters and the thick peat vegetation cover above the cave suggests that in this cave such kinetic effects on $\delta^{18} \mathrm{O}$ are likely to be minimal.

\subsection{The sensitivity of $\delta^{18} \mathrm{O}$ to record climate conditions}

Using the monitoring data, the sensitivity of $\delta^{18} \mathrm{O}_{c}$ to changing meteorological conditions over the instrumental period (1874 AD-present) can be tested. Firstly, the annual weighted mean $\delta^{18} \mathrm{O}_{\mathrm{ppt}}$ for each year is calculated. This is 
Table 5. Predicted $\delta^{18} \mathrm{O}$ values for calcite $\left(\delta^{18} \mathrm{O}_{c}\right)$ on the $\mathrm{V}$ PDB scale from measured temperature and water isotope composition $\left(\delta^{18} \mathrm{O}_{w}\right)$ on the V-SMOW scale, calculated from Kim and O'Neil (1997). The oxygen isotope fractionation factor $(\alpha)$ between calcite and water was experimentally determined by these authors and can be expressed as $1000 \ln \alpha=18.03^{*}\left(10^{3} / T\right)-32.42$ where $T$ is temperature in Kelvin. Calcite composition on the PDB scale is given by $0.97002 *\left(\alpha *\left(1000+\delta^{18} \mathrm{O}_{w}\right)-1000\right)-29.98$.

\begin{tabular}{lrrr}
\hline Temperature $\left({ }^{\circ} \mathrm{C}\right)$ & \multicolumn{3}{c}{ Water $\delta^{18} \mathrm{O}(\% o)$} \\
\hline & $\begin{array}{r}\text { Min } \\
(-7.66)\end{array}$ & $\begin{array}{r}\text { Mean } \\
(-7.09)\end{array}$ & $\begin{array}{r}\text { Max } \\
(-5.99)\end{array}$ \\
\hline Min (4.8) & -5.6 & -5.1 & -4.0 \\
Mean (7.2) & -6.2 & -5.6 & -4.5 \\
Max (9.5) & -6.7 & -6.1 & -5.0 \\
\hline
\end{tabular}

Table 6. Actual $\delta^{18} \mathrm{O}_{c}$ values of $0.1 \mathrm{~mm}$ sub-samples of the top $1 \mathrm{~mm}$ and $0.5 \mathrm{~mm}$ of stalagmites SU96-7 and SU03-2.

\begin{tabular}{lllll}
\hline & \multicolumn{2}{c}{ SU96-7 } & \multicolumn{2}{c}{ SU03-2 } \\
\hline & $(1 \mathrm{~mm})$ & $(0.5 \mathrm{~mm})$ & $(1 \mathrm{~mm})$ & $(0.5 \mathrm{~mm})$ \\
\hline Mean & -5.1 & -5.1 & -5.3 & -5.3 \\
Min & -5.6 & -5.4 & -5.5 & -5.5 \\
Max & -4.8 & -4.8 & -5.1 & -5.1 \\
\hline
\end{tabular}

done using the corrected Stornoway temperature and precipitation series (Proctor et al., 2000) which extend back from the present to $1879 \mathrm{AD}$ and the multiple linear regression equations found between $\delta^{18} \mathrm{O}_{\mathrm{ppt}}$ and climate at our field site (based on 2-y monitoring period) and Valentia (IAEA GNIP site), based on a longer though discontinuous 44-y monitoring period.

The regression equations for the two locations are as follows:

Inchnadamph $\delta^{18} O_{\mathrm{ppt}}=-0.015 \times \mathrm{PPT}$ amount -3.92

Valentia $\delta^{18} O_{\mathrm{ppt}}=0.199 \times T-0.008 \times \mathrm{PPT}$ amount -6.28

Using the monthly climate data from AD 1879 to present (Proctor et al., 2000), the monthly and annual $\delta^{18} \mathrm{O}_{\mathrm{ppt}}$ from $\mathrm{AD} 1879$ to present are hindcast. Because it has already been shown that the mean annual $\delta^{18} \mathrm{O}_{w}$ is close to mean annual $\delta^{18} \mathrm{O}_{\mathrm{ppt}}$ this value is inserted together with mean annual temperature into the equation of Kim and O'Neill (1997). Figure 6 shows the results in comparison with $\delta^{18} \mathrm{O}_{c}$ data from stalagmite SU96-7 at an average resolution of $2.5 \mathrm{y}$ (the age error is within this resolution). The stalagmite chronology

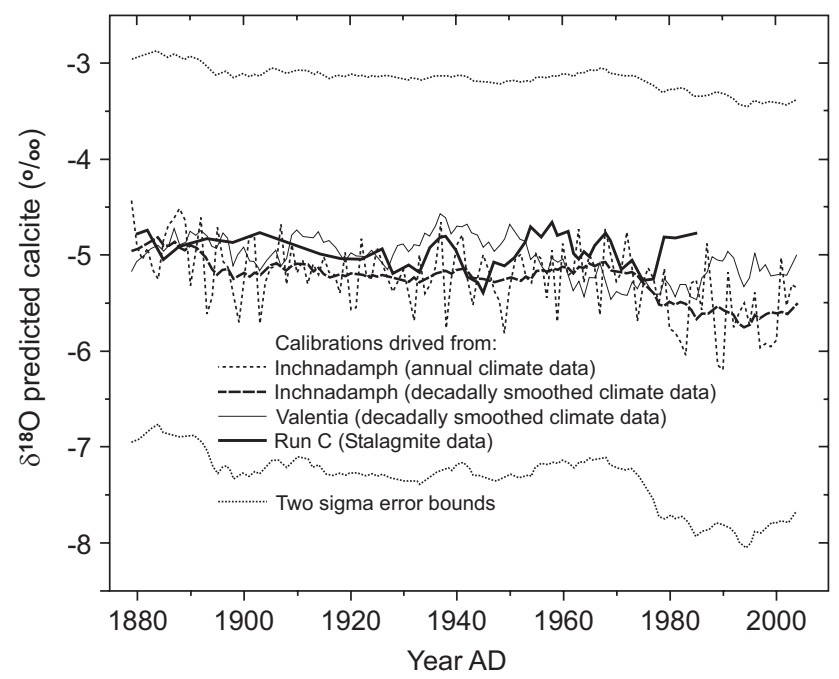

Fig. 6. Plot showing the predicted or hindcast $\delta^{18} \mathrm{O}_{c}$ values of Tartair stalagmites using calibrations derived from both the 2-y study site monitoring data and also using the longer-term data recorded at the IAEA-GNIP Valentia site. Actual $\delta^{18} \mathrm{O}_{c}$ of a Tartair stalagmite (SU96-7, run C) is also shown.

has been derived by comparison with the annual fluorescent lamina width time series (Proctor et al., 2000). A close similarity of the absolute values hindcast from both Valentia and the local rainfall, and measured in the stalagmite, can be observed. The $\delta^{18} \mathrm{O}_{c}$ values display a slight trend towards lighter values over time, with a visually a closer match provided by Eq. (3) from the Valentia data than Eq. (2) from the local data, at least for the first half of the twentieth century. However, the local calibration is more limited since it depends mostly on rainfall variability, given that the 2-y calibration period $(n=22)$ was too short to capture any significant temperature variation. The short local observation period also contributes to the width of the error bars associated with the hind-cast; the clustering of all three time series around the mean suggests that with a longer calibration period the hindcast data would still agree with stalagmite observations within errors. From this hindcasting exercise it can be seen that isotopically depleted $\delta^{18} \mathrm{O}_{c}$ is associated with wet and warm periods, whereas isotopically heavy calcite is characteristic of dry and cold years. Calcite deposited during dry and warm, or wet and cold years lies in-between. This result is of considerable interest in improving the climatic interpretations from this site over the past millennium, since the published interpretations based on lamina thickness contrast warm, dry years (leading to enhanced growth) with cool, wet years (Proctor et al., 2000, 2002). Hence the two proxies should provide complementary information. 


\section{Conclusions}

Monitoring of atmospheric precipitation found a range of $7.1 \%$ in $\delta^{18} \mathrm{O}_{\mathrm{ppt}}$ values. No correlation is found between $\delta^{18} \mathrm{O}_{\mathrm{ppt}}$ and temperature over the 2 -y monitoring period, but a negative linear correlation is found with precipitation amount. Drip water $\delta^{18} \mathrm{O}$ is attenuated compared to $\delta^{18} \mathrm{O}_{\mathrm{ppt}}$ : no drip displayed more than $1.2 \%$ variation in the observation period and their mean composition was close to that of the annually-weighted precipitation. This indicates that the autogenic drip waters are dominated by a large component of stored water ( $>1 \mathrm{y}$ old) which is relatively well mixed. Drip rate monitoring and measurements of EC reinforce this observation, drip rate being particularly constant for the drip that fed stalagmite SU96-7 that was analyzed for the hindcasting exercise. The predicted isotopic composition of calcite that should precipitate from these cave waters under the current range of cave temperatures is $0.5-$ $0.7 \%$ lighter than that of contemporary calcite of two actively growing stalagmite tips, using the more recent fractionation factors. This small offset is diminished when the actual $\delta^{18} \mathrm{O}_{c}$ values are compared to predictions made using minimum temperature, consistent with other evidence of faster winter growth. Hence, if there is a kinetic isotope effect during precipitation of calcite, it is relatively small. Kinetic fractionation is not thought to play a significant role during calcite deposition due to the cold cave temperatures, the steady non-flashy nature of the cave drips and the thick peat cover above the cave. Hindcasting of the isotopic composition of calcite deposited during the instrumental climate record period (AD 1879-present) shows that this cave is sufficiently sensitive and has good potential for the development of a longer series of proxy climate records based on oxygen isotopes that will complement published interpretations derived from other proxies in the studied stalagmite.

Acknowledgements. We would like to thank: Gina Moseley, Catherine Jex, Claire Smith, Cat Muller, Jen Moss, James and Lisa Baldini for the help in the field, Chris Rix for collection of water samples, and Richard Johnson for providing the field equipment. Two anonymous referees and George Darling made significant suggestions for improvement of the paper. This research was funded by NERC (studentship NER/S/S/2003/11964) and formed part of the ASCRIBE project (NERC grant reference $\mathrm{NER} / \mathrm{T} / \mathrm{S} / 2002 / 0448$ ) in the RAPID climate change thematic program.

Edited by: J. Freer

\section{References}

Atkinson, T. C.: Diffuse flow and conduit flow in limestone terrain in the Mendip Hills, Somerset (Great Britain), J. Hydrol., 35, 93-110, 1977.

Baker, A. and Brunsdon, C.: Non-linearities in drip water hydrology: an example from Stump Cross Caverns, Yorkshire, J. Hydrol., 277, 151-163, 2003.

Baker, A., Barnes, W. L., and Smart, P. L.: Variations in the discharge and organic matter content of stalagmite drip waters in Lower Cave, Bristol, Hydrol. Process., 11, 541-555, 1997.

Baker, A., Proctor, C. J., and Barnes, W. L.: Stalagmite lamina doublets: a 1000 year proxy record of severe winters in Northwest Scotland, Int. J. Climatol., 22, 1339-1345, 2002.

Baldini, J. U. L., McDermott, F., Baker, A., Baldini, L. M., Mattey, D. P., and Railsback, L. B.: Biomass effects on stalagmite growth and isotope ratios: A 20th century analogue from Wiltshire, England, Earth Planet. Sc. Lett., 240, 486-494, 2005.

Baldini, J. U. L., McDermott, F., and Fairchild, I. J.: Spatial variability in cave drip water hydrochemistry: Implications for stalagmite paleoclimate records, Chem. Geol., 235, 390-404, 2006.

Bar-Matthews, M., Ayalon, A., Matthews, A., Sass, E., and Halicz, L.: Carbon and oxygen isotope study of the active watercarbonate system in a karstic Mediterranean cave: Implications for paleoclimate research in semiarid regions, Geochim. Cosmochim. Ac., 60, 337-347, 1996.

Begley, I. S. and Scrimgeour, C. M.: High-precision $\mathrm{d} 2 \mathrm{H}$ and d180 measurement for water and volatile organic compounds by continuous-flow pyrolysis isotope ratio mass spectrometry, Anal. Chem., 69, 1530-1535, 1997.

Caballero, E., Jimenez De Cisneros, C., and Reyes, E.: A stable isotope study of cave seepage waters, Appl. Geochem., 11, 583587, 1996.

Charman, D., Caseldine, C., Baker, A., Gearey, B., Hatton, J., and Proctor, C. J.: Paleohydrological Records from Peat Profiles and Speleothems in Sutherland, Northwest Scotland, Quaternary Res., 55, 223-234, 2001.

Colman, A.: Prediction of summer central England temperature from preceding North Atlantic winter sea surface temperature, Int. J. Climatol., 17, 1285-1300, 1997.

Darling, W. G. and Talbot, J. C.: The O and H stable isotopic composition of fresh waters in the British Isles, 1. Rainfall, Hydrol Earth Syst. Sc., 7, 163-181, 2003.

Denniston, R. F. Gonzalez, L. A., Asmerom, Y., Baker, R. G., Reagan, M., and Bettis, E. A.: Evidence for increased cool season moisture during the middle Holocene, Geology, 27, 815-818, 1999.

Destombes, J. L., Cordonnier, M., Gadat, Y. J., and Delannoy, J. J.: Periodic and aperiodic forcing of water flow through soda straw stalactites (Choranche, Vercors, France), 6th Conference on Limestone Hydrology and Fissured Media, Basel, Switzerland, 69-72, 1997.

Fairchild, I. J., Borsato, A., Tooth, A. F., Frisia, S., Hawkesworth, C. J., Huang, Y., McDermott, F., and Spiro, B.: Controls on trace element $(\mathrm{Sr}-\mathrm{Mg})$ compositions of carbonate cave waters: implications for speleothem climatic records, Chem. Geol., 166, 255269, 2000.

Fairchild, I. J., Smith, C. L., Baker, A., Fuller, L., Spötl, C., Mattey, D., McDermott, F., and E. I. M. F.: Modification and preservation of environmental signals in speleothems, Earth Science Reviews, 
75, 105-153, 2006a.

Fairchild, I. J., Tuckwell, G. W., Baker, A., and Tooth, A. F.: Modelling of dripwater hydrology and hydrogeochemistry in a weakly karstified aquifer (Bath, UK): implications for climate change studies, J. Hydrol., 321, 213-231, 2006 b.

Friedman, I. and O'Neil, J.R.: Compilation of stable isotope fractionation factors of geochemical interest, US Geological Survey Professional paper 440-KK, 49 pp., 1977.

Friederich, H. and Smart, P. L.: The classification of autogenic percolation waters in Karst Aquifers: A study in G. B Cave, Mendip Hills, England, Uni. Bristol Spael. Soc. Proc., 16, 143159, 1982.

Fuller, L.: High-resolution multiproxy geochemical Holocene climate records from 1000-year old Scottish stalagmites, Unpublished $\mathrm{PhD}$ thesis, University of Birmingham, UK, 2007.

Genty, D. and Deflandre, G.: Drip flow variations under stalactite of the Pere Noel cave (Belgium). Evidence of seasonal variations and air pressure constraints, J. Hydrol., 211, 208-232, 1998.

Gunn, J.: Hydrological Processes in karst depressions, Z. Geomorphol., 25, 313-331, 1981.

Hoffmann, G., Werner, M., and Heimann, M.: Water isotope module of the ECHAM atmospheric general circulation model: A study of timescales from days to several years, J. Geophys. Res., 103, 16871-16896, 1998.

Hurrell, J. W.: Decadal trends in the North-Atlantic oscillation regional temperatures and precipitation, Science, 269, 676-679, 1995.

Kay, R. L. F., Andrews, J. N., Bath, A. H., and Ivanovich, M.: Groundwater flow profile and residence times in crystalline rocks at Altnabreac, Caithness, UK, in: IAEA (Organizational Editor), Isotope Hydrology, Vienna, Austria, 231-248, 1984.

Kim, S. T. and O’Neil, J. R.: Equilibrium and non-equilibrium oxygen isotope effects in synthetic carbonates, Geochimica et Cosmochimica Acta, 61, 3461-3475, 1997.

Lawson, T. J.: Caves of Assynt, The Grampian Speleological Group, Edinburgh, 1988.

Leng, M. J. and Marshall, J. D.: Palaeoclimate interpretation of stable isotope data from lake sediment archives, Quaternary Sci. Rev., 23, 811-831, 2004.

Mangin, A.: Contribution à l'étude des aquifères karstiques, Annales de Speleologie, 29, 21-124, 1975.

McDermott, F.: Palaeo-climate reconstruction from stable isotope variation in speleothems: a review, Quaternary Sci. Rev., 23, 901-918, 2004.

McDermott, F., Schwarcz, H., and Rowe, P. J.: 6. Isotopes in Speleothems, in: Isotopes in Palaeoenvironmental Research, edited by: Leng, M. J., Springer, Dordrecht, The Netherlands, 185-225, 2005.

Mickler, P. J., Stern, L. A., and Banner, J. L.: Large kinetic isotope effects in modern speleothems, Geol. Soc. Am. Bull., 118, 6581, 2006.

Mook, W. G.: Environmental Isotopes in the Hydrological Cycle, Volume II (Atmospheric Water) UNESCO, Paris/IAEA, Vienna, 2000 .
Proctor, C. J., Baker, A., and Barnes, W. L.: A three thousand year record of North Atlantic Climate, Clim. Dynam., 19, 449-454, 2002.

Proctor, C. J., Baker, A., Barnes, W. L., and Gilmour, M.: A thousand year speleothem proxy record of North Atlantic climate from Scotland, Clim. Dynam., 16, 815-820, 2000.

Rozanski, K., Araguas-Araguas, L., and Gonfiantini, R.: Isotopic patterns in modern global precipitation, in: Climate Change in continental Isotopic Records, edited by: Swart, P. K., Lohmann, K. L., McKenzie, J., and Savin, S., Geophysical Monograph 78, Americal Geophysical Union, Washington D.C., 1-37, 1993.

Smart, P. L. and Friederich, H.: Water movement and storage in the unsaturated zone of a naturally karstified aquifer, Mendip Hills, England, Conference on Environmental Problems in Karst Terrains and their solution, National Water Well Association, Bowling Green, Kentucky, 57-87, 1987.

Smith, C. L., Baker, A., Fairchild, I. J., Frisia, S., and Borsato, A.: Reconstructing hemispheric-scale climates from multiple stalagmite records, Int. J. Climatol., 26, 1417-1424, 2006.

Spötl, C. and Vennemann, T. W.: Continuous-flow isotope ratio mass spectrometric analysis of carbonate minerals, Rapid Commun. Mass Sp., 17, 1004-1006, 2003.

Thornthwaite, C. W.: An approach towards a regional classification of climate, Geogr. Rev., 38, 55-94, 1948.

Tooth, A. F. and Fairchild, I. J.: Soil and karst aquifer hydrological controls on the geochemical evolution of speleothem-forming drip waters, Crag Cave, southwest Ireland, J. Hydrol., 273, 5168, 2003.

Treble, P., Budd, W. F., Hope, P. K., and Rustomji, P. K.: Synopticscale climate patterns associated with rainfall delta O-18 in southern Australia, J. Hydrol., 302, 270-282, 2005a.

Treble, P., Chappell, J., Gagan, M. K., McKeegan, K. D., and Harrison, T. M.: In situ measurement of seasonal $\delta^{18} \mathrm{O}$ variations and isotopic trends in a modern speleothem from southwest Australia, Earth Planet. Sc. Lett., 233, 17-32, 2005 b.

van Beynen, P. and Febbroriello, P.: Seasonal isotopic variability of precipitation and cave drip water at Indian Oven Cave, New York, Hydrol. Process., 20, 1793-1803, 2006.

Wang, Y. J., Cheng, H., Edwards, R. L., An, Z. S., Wu, J. Y., Shen, C. C., and Dorale, J. A.: A high-resolution absolute dated Late Pleistocene monsoon record from Hulu Cave, China, Science, 294, 2345-2348, 2001.

Wigley, T. M. L. and Brown, M. C.: The physics of caves, in: The Science of Speleology, edited by: Ford, D. C. and Cullingford, C. H. D., Academic Press, London, 329-358, 1976.

Williams, P. W. and Fowler, A.: Relationship between oxygen isotopes in rainfall, cave percolation waters and speleothem calcite at Waitomo, New Zealand, J. Hydrol. (NZ), 41, 53-70, 2002.

Yonge, C., Ford, D. C., Gray, J., and Schwarcz, H. P.: Stable isotope studies of cave seepage water, Chem. Geol., 58, 97-105, 1985. 